\title{
Loops de Bol 2-nilpotentes e de expoente 2
}

\author{
Cristina Spohr
}

TESE APRESENTADA

$\mathrm{AO}$

Instituto De Matemática e Estatística

DA

Universidade DE SÃo PAulo

PARA

OBTENÇÃO DO TÍTULO

$\mathrm{DE}$

DOUTOR EM CIÊNCIAS

\author{
Programa: Matemática \\ Orientador: Prof. Dr. Alexandre Grichkov
}

Durante o desenvolvimento deste trabalho a autora recebeu auxílio financeiro do CNPq

São Paulo, março de 2010 